\title{
PEDAGOGICAL PRACTICES IN HIGHER EDUCATION: IMPROVING STUDENTS' COMPETENCES THROUGH CROSS-CURRICULAR PROBLEM-SOLVING ACTIVITIES
}

\author{
Ana Rita Calvão', Sílvia Ribeiro ${ }^{1,2}$, Anabela Simões ${ }^{1,2}$ \\ ${ }^{1}$ ESTGA - Higher School of Technology and Management of Águeda - University of Aveiro \\ (PORTUGAL) \\ ${ }^{2}$ CLLC - Languages, Literatures and Cultures Research Centre - University of Aveiro \\ (PORTUGAL)
}

\begin{abstract}
Similarly to its European counterparts, Portugal's Higher Education system has undergone profound changes as a result of the Bologna Process. Even though some difficulties in the adaptation to new teaching-learning practices have been reported [1], [2], at the Higher School of Technology and Management of the University of Aveiro the required paradigm shift in education has been implemented, namely through problem-based learning activities and, consequently, through competences aggregation between different curricular units (CU) [3], a methodology that implies the articulation between concomitant courses of a study programme.

Since 2016/2017, cross-curricular problem-solving projects are being developed within the 1st cycle degree in Office Management and Business Communication: Electronic Office Applications II (EOAII) articulates with Portuguese II (PII) ( $2^{\text {nd }}$ semester courses) and Data Analysis (DA) articulates with Secretarial Techniques II (STII) ( $3^{\text {rd }}$ semester courses). The option for competences articulation aims primarily at consolidating skills in key areas for secretarial and communication professionals [4] such as languages, electronic office applications and data analysis. Since 2016/2017, 63 students from 3 different classes have been involved.

Within the $2^{\text {nd }}$ semester project, two practical assignments were requested: in the first one, students produced and presented a monograph and a scientific poster; in their second assignment, they prepared a labour market integration portfolio. For the accomplishment of both tasks, competences underlying the two associated CUs converged: in PII students acquired research and information selection skills, as well as structuring, writing and text revision competences; while resourcing to various tools (e.g., Publisher, PowerPoint, Prezi, Word, Canva, Wix, Powton, etc.), EOAll students developed their design and layout development skills. For the $3^{\text {rd }}$ semester project, the production and oral presentation of a statistical report were requested. For the creation of their questionnaires, students applied skills intrinsic to the two courses involved. After having collected and processed the statistical data (DA), students structured and wrote their reports (STII).

Cross-curricular projects, in addition to allowing a higher return on students' efforts (the same task is assessed in two different CUs), also emphasise the transversal nature of learning, clarifying that knowledge and skills associated with a given CU can have a concrete application in the real world, always in articulation with competences from other backgrounds. This is a clearly student-centred approach, one that provides students with the opportunity to consolidate technical and interpersonal skills essential to their professional success in an ever more collaborative environment, contributing thus to the "creation of a professional profile that meets the labour market and society's expectations" [5].
\end{abstract}

Keywords: higher education, cross-curricular projects, office management, business communication, competences.

\section{INTRODUCTION}

As in all of Europe, the Bologna Process and the creation of the European Higher Education Area have brought profound changes to the Portuguese higher education (HE) system. To a large extent, in addition to the significant reform in the structuring of $\mathrm{HE}$ in three cycles and the implementation of the ECTS system, these alterations are associated with the transition from a more passive, teachercentred model that aims at students' knowledge acquisition, to a paradigm where students assume the 
main role, a model that seeks to create an environment that facilitates competences development and consolidation [6], [7].

All these transformations pose considerable challenges to the daily lives of the involved subjects, namely students and faculty; nevertheless, several studies applied to national and international contexts [1], [2] reveal that these changes have not always occurred with the necessary strength and depth.

Indeed, even if the necessity and benefits of the changes inherent to the new European HE paradigm are evident, they will only be effective if they are accompanied by a change of attitude, mindset, and ways of working [8]. This paradigm shift implies a student-centred education, an adjustment to the teacher's role, a switch in the focus of educational activities, and a clear adjustment in the organisation of learning. It is therefore fundamental not only to focus on new teaching practices but also to focus on experimental and hands-on approaches, as well as to encourage collaboration between teachers in order to guarantee new formative environments clearly marked by interdisciplinarity. Only in this way can HE institutions be able to train graduates who have the technical and transversal competences expected by today's employers, who increasingly value functional polyvalence [8].

This work aims to present an interdisciplinary articulation experiment that is underway at the Higher School of Technology and Management of the University of Aveiro (ESTGA-UA) since 2016/2017. The proposed activities aim not only to promote the development of multiple transversal skills but also the consolidation of technical competences in three fundamental areas of the $1^{\text {st }}$ cycle degree in Office Management and Business Communication: Languages, Computer Applications and Data Analysis.

\section{CONTEXT}

At ESTGA-UA, the Project-Based Learning (PBL) model has been adopted by technology and engineering degrees since 1999. It is a student-centred teaching method that responds to one of the core challenges of the Bologna Process. In this context, students "depart from concrete, real-world problems that assume the form projects, and develop of all their learning around efforts to solve these problems. The learning processes are thus autonomous, different from student to student and from any route pre-defined by teachers" [9].

Simultaneously, in non-technological study programmes taught at ESTGA-UA, PBL guidelines are also followed, not only through the introduction of projects in their curricular plans, but, especially, through the organisation of pedagogical activities around competences aggregations (CA), "which translate into an articulation between several curricular units with the intention of developing main themes of the course in an integrated way" [9]. Within this framework, students are asked to develop assignments where content and competences inherent to each $\mathrm{CU}$ are present; the process is monitored and assessed by several teachers who collaborate regularly during all stages of the crosscurricular activity.

The option for the aggregation of competences from different CUs - and, therefore, from different fields of training - is extremely important, especially when preparing professionals who, due to the characteristics of the profession itself, must be versatile and flexible, as is the case of office management professionals. In reality and according to [10], these professionals are no longer only responsible for the direct support to top managers, they have also come to assume increasing responsibilities as regards the interaction with multiple organisational partners. As stated on the homepage of the Portuguese Association of Professional Secretaries website, these are professionals who, as a result of the changes in organisational structures, are now assuming a "more prominent, visible, active, intervening and autonomous role, one that implies greater responsibility" [11].

In order to meet these requirements, office management professionals "must have knowledge and skills related to the company, to intercultural communication, interpersonal relationships and languages, information management and new technologies, as well as the ability to learn and adapt to changes" [12]. Therefore, any course structure in this field must be markedly multidisciplinary and focused on the development of technical and transversal competences adjusted to organisations' needs and to the practicable exercise of the profession [13].

At ESTGA-UA, the $1^{\text {st }}$ cycle degree in Office Management and Business Communication (OMBC) was structured to provide students with a multidisciplinary training. It includes CUs of eight scientific fields - Languages, Secretarial Studies and Business Communication, Social Sciences, Information Technology, Management, Legal Sciences, Mathematics and Accounting -, and it also includes a 
Free Option CU, which allows students the opportunity to further study contents from a scientific field of their choice.

In this context, and considering the multidisciplinary nature associated with most of the training semesters of these students, since 2016/2017, a two-consecutive-semester cross-curricular activity has been developed, with the main goal of reinforcing students' competences in three core domains: languages (specifically, the students' mother tongue), computer applications, and data collection and processing.

With this in mind, in the last three academic years, we have chosen to aggregate competences between the CUs Electronic Office Applications II (EOAII) and Portuguese II (PII) (2 ${ }^{\text {nd }}$ semester courses), and Data Analysis (DA) and Secretarial Techniques II (STII) ( ${ }^{\text {rd }}$ semester courses). The selection of these CUs for the accomplishment of the aggregation is based on the fact that the respective contents - as well the learning outcomes that underlie them - are closely articulated in different competences associated with the ideal higher education profile of these professionals, as indicated by [12]. In the next section, we describe this CA experiment, explaining (i) the challenges posed to the students, (ii) the objectives of each aggregation, (iii) the adopted work and assessment methodologies. Subsequently (section 3.2), the results of a survey applied to the involved students shall be presented; this examination not only reveals the degree of students' satisfaction after this differentiating pedagogical practice, it also allows the identification, from a student perspective, of the developed and consolidated technical and transversal competences in such contexts.

\section{COMPETENCES AGGREGATION IN OFFICE MANAGEMENT AND BUSINESS COMMUNICATION: DESCRIPTION OF THE EXPERIMENT}

In the following paragraphs, the $\mathrm{CA}$ experiments conducted within the undergraduate degree in OMBC since 2016/2017 shall be described.

\subsection{Developed cross-curricular problem-solving activities}

The cross-curricular experiments presented in this paper began in the second semester of academic year 2016/2017. Since then, 63 students from three different classes have been involved, as shown in Table 1.

Table 1. Number of students involved in competences aggregation activities

\begin{tabular}{c|c|c|c}
\hline \hline & $2016 / 2017$ & $2017 / 2018$ & $2018 / 2019$ \\
\hline $2^{\text {nd }} \begin{array}{c}\text { semester aggregation } \\
\text { (EOAII + PII) }\end{array}$ & 21 & 23 & 19 \\
\hline $\begin{array}{c}3^{\text {rd }} \text { semester aggregation } \\
\text { (DA+STII) }\end{array}$ & --------- & 20 & 21 \\
\hline \hline
\end{tabular}

In the $2^{\text {nd }}$ semester, in the scope of the aggregation of competences between EOAll and PII, two practical assignments (PA) were proposed to students. In the first PA, a group assignment, students were asked to produce a monograph and a poster about a topic suggested by the teachers, which were then followed by an oral presentation. In the second PA, an individual assignment, students were requested to produce a labour market integration file, containing a real job advertisement selected by students, the respective application letter, a printed $\mathrm{CV}$, and a personal web page. All documents were presented and discussed as part of a final oral test that simulated a job interview situation. Fig. 1 shows the expected products in each of the PAs proposed within the scope of this CA.

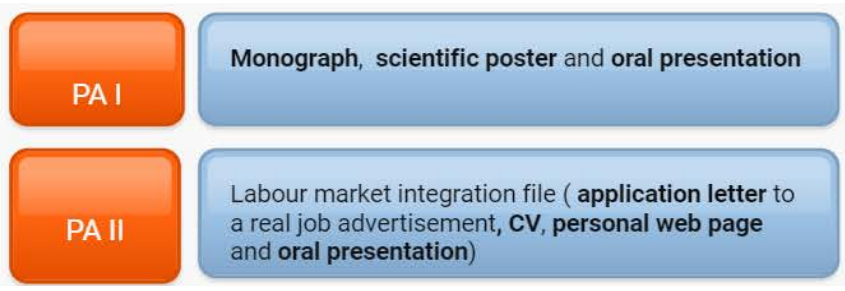

Figure 1. Developed practical assignments. 
The type of tasks suggested, as well as the proposed assessment methodology, were defined according to the programme contents and the learning objectives of both CUs involved. While completing the two PAs, students converged competences that were meant to be developed in both CUs, as illustrated in Fig. 2.

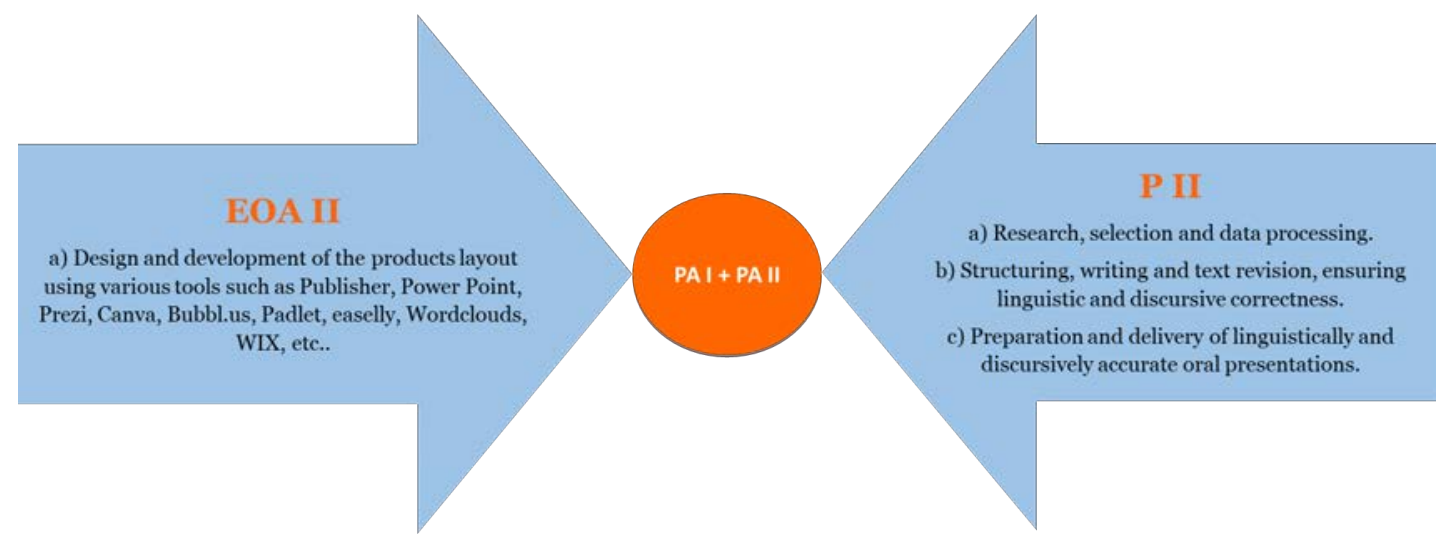

Figure 2. EOA II and P II: converged competences.

In the first two years of this cross-curricular experiment (2016/2017 and 2017/2018), the guidelines associated with the practical assignments were presented separately by each of the teachers involved. In each of the documents - both explained to class and published in each CU's work area of the eLearning platform adopted by the University of Aveiro - the products to be developed by students were identified and the objectives underlying the assignments, the different steps and deadlines to be considered, as well as the assessment criteria were clarified. The development of the assignments was regularly followed by the teachers involved, but in a non-concomitant fashion. Both teachers attended the oral presentations and assessed the aspects relevant to each of their CU.

In 2018/2019 and after considering the suggestions of the previously involved students, the teachers optimised the preparation of the aggregation by elaborating a single joint guide, which gathered information and orientations for the development of students' PAs. On the first day of class, both teachers presented the document with the defined guidelines, which was then made available in both work areas of the elearning platform. This document contained the information mentioned above but was organised to clearly highlight the contribution of each $\mathrm{CU}$, as shown in Table 2, which outlines some elements considered in the assessment of PA I.

Table 2. PA I assessment criteria: some considered elements

\begin{tabular}{|l|l|}
\hline \multicolumn{1}{|c|}{ EOAll } & \multicolumn{1}{|c|}{ PII } \\
\hline $\begin{array}{l}\text { This work (PA I) corresponds to 20\% of the CU's } \\
\text { final grade. }\end{array}$ & $\begin{array}{l}\text { This work (PA I) corresponds to 30\% of the CU's final } \\
\text { grade. }\end{array}$ \\
\hline $\begin{array}{l}\text { The final grade will be obtained considering the } \\
\text { following aspects: }\end{array}$ & $\begin{array}{l}\text { The final grade will be obtained considering the following } \\
\text { partial scores: }\end{array}$ \\
$\checkmark \quad$ Work developed over the semester ** & $\checkmark$ Work developed over the semester $-10 \%{ }^{* *}$ \\
$\checkmark$ Poster * & $\checkmark$ Monograph $-40 \%$ * \\
$\checkmark$ Oral presentation ** & $\checkmark$ Poster $-35 \%$ * \\
$*$ the same grade will be given to all members of & $\checkmark$ Oral presentation $-15 \%$ ** \\
the group & ${ }^{*}$ the same grade will be given to all members of the group \\
$*$ grades will be given individually & $* *$ grades will be given individually \\
\hline
\end{tabular}




\begin{tabular}{|l|l|}
\hline $\begin{array}{l}\text { Assessed elements: } \\
\text { Work developed over the semester }\end{array}$ & $\begin{array}{l}\text { Assessed elements: } \\
\text { Work developed over the semester }\end{array}$ \\
\hline - Meeting deadlines & - Meeting deadlines \\
- $\begin{array}{l}\text { Ability to manage and integrate } \\
\text { - Active participation }\end{array}$ & - Ability to research, select and handle information \\
- Autonomy & - Autonomy \\
- Creativity & - Creativity \\
Poster & Monograph and Poster \\
- Correctness and relevance of the & - Correctness and relevance of the collected and \\
- Collected and presented information & - Correctness and adequacy of the delivered \\
- Colivered documents & - Locuments \\
- Creativity and critical thinking & - Creativity and critical thinking \\
- Intellectual honesty & - Intellectual honesty, referencing and citation \\
\hline
\end{tabular}

Over the course of the semester, a close follow-up of the work in progress was ensured, on the one hand, through the allocation of class time in each of the CUs and, on the other hand, through the definition of office hours specifically directed to the clarification of questions and doubts related to the assignments in which both teachers were present. The assessment of these PAs was also articulated, with the same product being evaluated, under different perspectives, by both teachers involved.

In the $3^{\text {rd }}$ semester, in the cross-curricular activities developed within the CUs Data Analysis and Secretarial Techniques II, students were requested to perform a practical group work. As in the previous semester's aggregation, the assignment was defined considering some of the contents and learning objectives associated with the aggregated CUs. The convergence of competences associated with the involved CUs occurred as described in Fig. 3, which also shows the final outputs presented by the students.

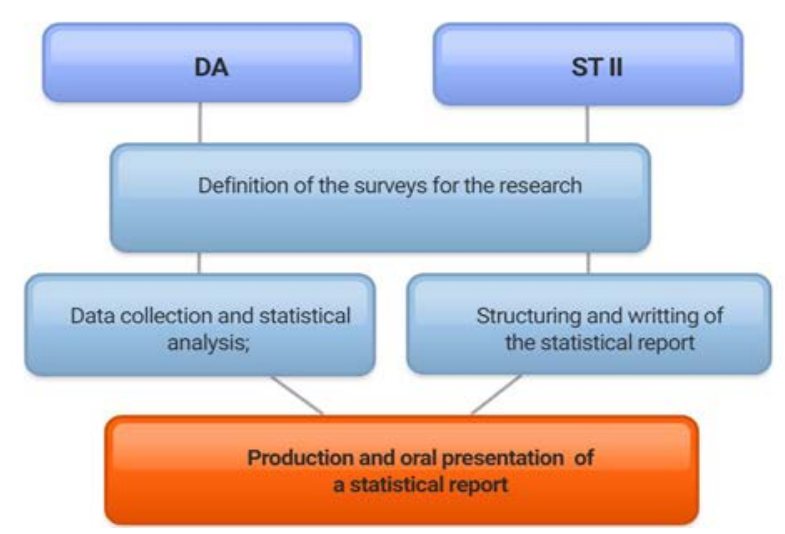

Figure 3. DA and ST II: converged competences and final outputs.

In the two years of implementation of this aggregation (2017/2018 and 2018/2019), and as happened in the first two editions of the $2^{\text {nd }}$ semester aggregation, different documents with guidelines were created for each of the CUs; these contained information about the objectives of the products to be developed, the deadlines to be met and the assessment criteria. In the context of this aggregation, the support provided by the teachers (in class and during office hours) was given separately. The final products (a statistical report followed by an oral presentation) were assessed in the scope of the two CUs, from different perspectives and according to the objectives of each course. Considering the experience garnered so far, it is expected to optimise this aggregation (in 2019/2020) in the same fashion it was implemented in the 2nd semester aggregation, with a greater articulation between teachers and with the creation of a common guide. 


\subsection{Student's perception of the cross-curricular activities}

To gather students' opinion regarding the CA experiments, an anonymous questionnaire was applied at the end of each semester. To do so, the GoogleForms tool was used. The questionnaire included a first set of questions, which aimed at assessing students' perception of the advantages and/or disadvantages of the CA model in relation to the traditional approach, and a second group of questions that sought to gauge the progress of the developed practical works. This second group of questions contained i) questions regarding students' perception of the clarity of the given indications, the way in which each CU would contribute to the work, and how they would be assessed by each teacher; ii) questions related to the technical competences developed and/or consolidated in each PA and iii) questions associated with transversal competences. The questionnaire ended with a comment space (non-mandatory response).

In all closed-ended questions, 5-level Likert-type scales were used, later coded from 1 to 5 . The following paragraphs present the obtained responses, which are organised into two groups: firstly, the results of $2^{\text {nd }}$ and $3^{\text {rd }}$ year students (who have already participated in the $2^{\text {nd }}$ and $3^{\text {rd }}$ semester aggregations) shall be presented; afterwards, the described results are the responses of students currently attending the $1^{\text {st }}$ year, who, therefore, were only involved in the $2^{\text {nd }}$ semester aggregation.

As to the $2^{\text {nd }}$ and $3^{\text {rd }}$ year classes, 19 responses (43\% of students) were obtained. From the $1^{\text {st }}$ year class, 14 answers were collected ( $74 \%$ of the students). Given the low number of responses from $2^{\text {nd }}$ and $3^{\text {rd }}$ year students, these will be analysed as a whole.

Overall, students who responded were very satisfied with the CA option, as shown in Table 3.

Table 3. Overall satisfaction of students involved in the cross-curricular activities

\begin{tabular}{|c|c|c|c|c|}
\hline & \multicolumn{2}{|c|}{$\begin{array}{c}\text { Cross-curricular project } \\
\text { EOA II + P II }\end{array}$} & \multicolumn{2}{|c|}{$\begin{array}{c}\text { Cross-curricular project } \\
\text { DA+ST II }\end{array}$} \\
\hline & Average & $\begin{array}{l}\text { Standard } \\
\text { deviation }\end{array}$ & Average & $\begin{array}{l}\text { Standard } \\
\text { deviation }\end{array}$ \\
\hline Group 1 ( $2^{\text {nd }}$ and $3^{\text {rd }}$ year classes) & 4.2 & 0.9 & 3.9 & 1.1 \\
\hline Group 2 (1 $1^{\text {st }}$ year class) & 4.8 & 0.4 & --- & --- \\
\hline
\end{tabular}

When questioned about the preference for the traditional approach or for the CA model, $74 \%$ of respondents from Group 1 (who had already participated in the two aggregations) opted for the latter, whereas $21 \%$ indicated they were indifferent to either one or the other option. As for Group 2, the preference for the CA model was practically unanimous, with only one student selecting the "Indifferent" option. Table 4 shows some of the advantages and disadvantages associated with the aggregation activities, according to students' view.

Table 4. Advantages and disadvantages of the aggregation activities, as indicated by students

\begin{tabular}{l|l}
\hline \hline \multicolumn{1}{c|}{ Advantages } & \multicolumn{1}{c}{ Disadvantages } \\
\hline $\begin{array}{l}\text { A smaller number of practical assignments } \\
\text { and subsequent workload reduction }\end{array}$ & $\begin{array}{l}\text { Apprehension about being assessed by } \\
\text { two teachers }\end{array}$ \\
\hline $\begin{array}{l}\text { Articulation between competences of } \\
\text { different areas }\end{array}$ & Longer practical assignments \\
\hline Greater proximity to the organisational reality & No disadvantages have been mentioned \\
\hline
\end{tabular}

Moreover, it should also be noted that the majority of students stated that there aren't any disadvantages in the CA model.

Fig. 4 indicates students' opinion as for (i) the clarity of the guidelines made available for each PA developed within aggregations, (ii) how each involved $\mathrm{CU}$ would contribute to the accomplishment of the before-mentioned PAs, and iii) how the assessment would be carried out. 


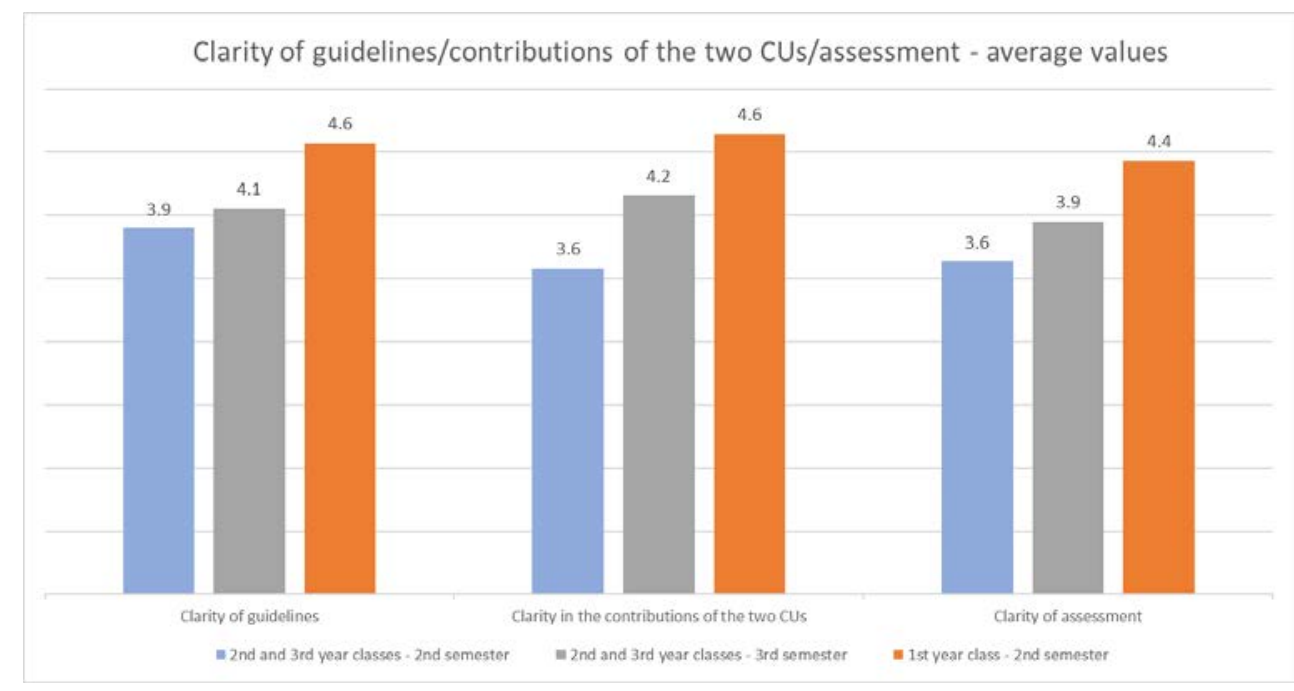

Figure 4. Clarity of guidelines, contributions of each $\mathrm{CU}$, and assessment.

Students of both groups considered that the indications given for the accomplishment of each PA were quite clear. In Group 1, an average of 3.9 (standard deviation of 0.8 ) was recorded in relation to the indications given for the $2^{\text {nd }}$ semester aggregation, and an average value of 4.1 for the $3^{\text {rd }}$ semester aggregation (standard deviation of 1.0). It is, thus, evident that students' satisfaction with this approach has increased over time, which may be related not only to greater familiarity with this model, but also to small improvements that teachers have been gradually integrating. In Group 2, the satisfaction values were even more satisfactory, with an average value of 4.6 (standard deviation of 0.5 ), which reflects the substantial optimisation of the process associated with the accomplishment of the $2^{\text {nd }}$ semester aggregation in the current academic year.

With regards to the clarity of the way in which each of the CUs would contribute to the work to be carried out, the obtained responses revealed trends similar to those described for the previous question. Thus, students from Group 1 indicated an average of 3.6 (standard deviation of 0.8 ) for the $2^{\text {nd }}$ semester aggregation and an average of 4.2 (standard deviation 1.1) for the $3^{\text {rd }}$ semester aggregation. As for Group 2, this question also stands out, with an average value of 4.6 (standard deviation of 0.6).

When questioned about the clarity of how the work developed within each aggregation would be assessed, the respondents from Group 1 indicated an average response of 3.6 (standard deviation of 1.1) for the $2^{\text {nd }}$ semester aggregation and 3.9 (standard deviation of 1.1) for the $3^{\text {rd }}$ semester aggregation. In Group 2, the obtained average value was 4.4 (standard deviation of 0.8 ).

An overall analysis of the data in Fig. 4 makes it clear that assessment is the criterion that students have considered tending to be less clear, but it is nevertheless evident that students are progressively satisfied with the three topics under analysis.

The students involved were also questioned about the technical and transversal competences developed and/or consolidated within the context of these experiments. Fig. 5 shows the results obtained in relation to the technical competences respondents affirm to have developed when carrying out the PA associated with the $2^{\text {nd }}$ semester aggregation. In this case, as both groups under analysis have already performed this aggregation, the values indicated by each group are compared. 


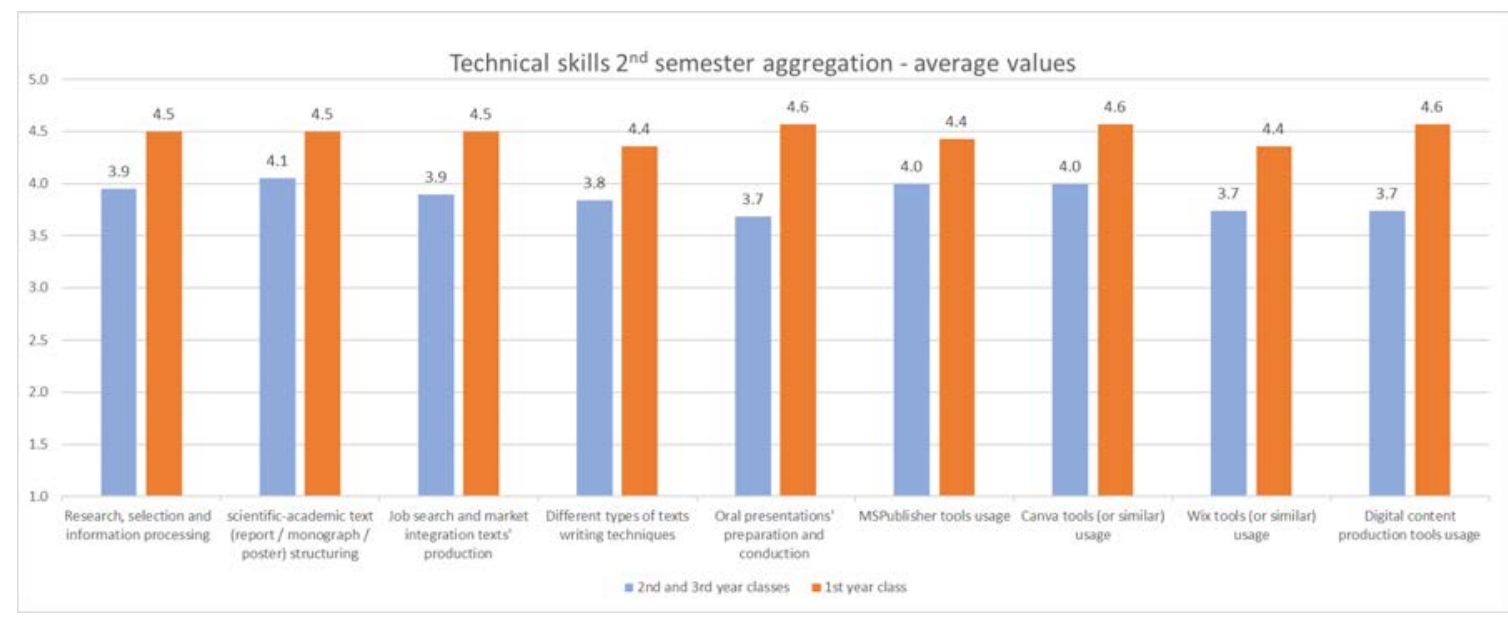

Figure 5. Technical skills developed within the $2^{\text {nd }}$ semester aggregation.

Overall, it is clear that students from Group 2 reported a higher level of consolidation of all technical skills that could be developed within this aggregation. In this context, responses for all the competences under analysis reached values equal or superior to 4.4. The competences that most stood out were the "Use of digital content production tools", "Use of the Canva tool or similar" and "Techniques for preparating and delivering oral presentations", with an average of 4.6 (standard deviation of 0.5 ) each. As for Group 1, the most valued competence was "Structuring of a scientificacademic text", with an average of 4.1 (standard deviation of 1.0), and "Using the MSPublisher tool" and "Using Canva tool or similar", with an average of 4.0 (standard deviation of 1.0).

Regarding the $2^{\text {nd }}$ semester aggregation, so far only the reponses of Group 1 are available; the results are presented in Fig. 6.

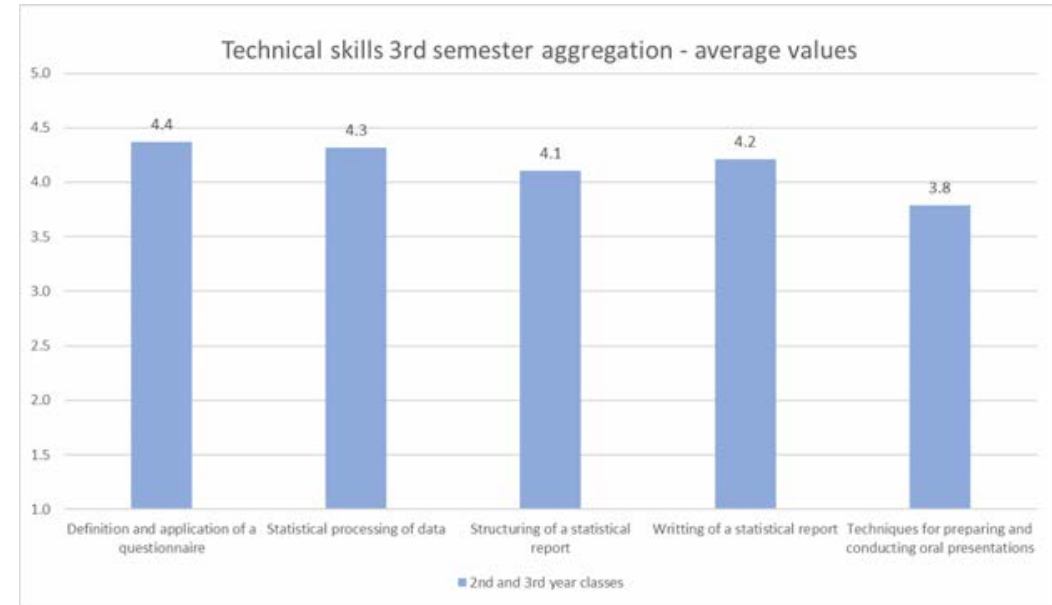

Figure 6. Group 1: technical skills developed within the $3^{\text {rd }}$ semester aggregation.

In this case, the most consolidated technical competence, according to respondents, is the "Preparation of a questionnaire and its application" (average of 4.4 and standard deviation of 1.1), followed by "Statistical treatment of data" (average of 4.3 and standard deviation of 1.1) and "Writing a statistical report" (average of 4.2 and standard deviation of 1.0). On the whole, the values of this group for this aggregation ( $3^{\text {rd }}$ semester) are higher than those obtained for the $2^{\text {nd }}$ semester aggregation, reflecting a progressive student satisfaction with this new approach and with the competences resulting from it.

Fig. 7 presents the responses obtained from both groups regarding the transversal competences developed and/or consolidated. Once again, Group 2 shows more favourable results. For this group, which attributes values higher than 4.0 to all competences, the most consolidated transversal competences were "Creativity" (average of 4.6 and standard deviation of 0.5 ) and "Problem solving and resolution of contingencies" (average of 4.5 and standard deviation of 0.5 ). 


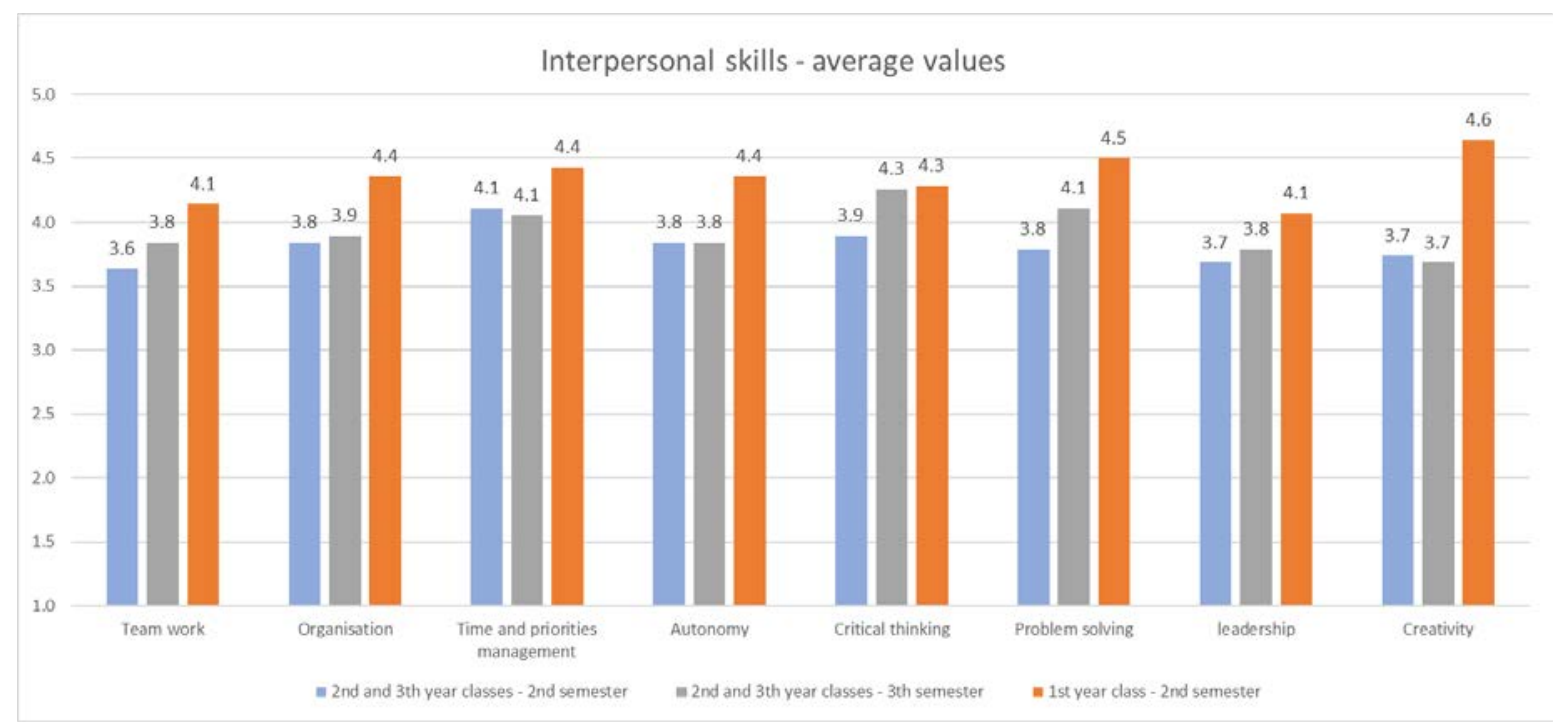

Figure 7. Developed interpersonal skills (average values).

Group 1 students indicated "Time and priority Management" (average of 4.1 and standard deviation of 0.9 ) and "Critical thinking" (average of 3.9 and standard deviation of 1.0) as the most significant competences developed within the $2^{\text {nd }}$ semester aggregation. In the context of the $3^{\text {rd }}$ semester aggregation, these students affirmed that the most developed competences were "Critical thinking" (average of 4.3 and standard deviation of 1.0) and "Problem solving and resolution of contingencies" (average of 4.1 and standard deviation of 1.0).

\section{CONCLUSIONS}

Overall, it is considered that the CA option has been progressively positive and that respondents are very satisfied with this new approach. It is not only clear that the surveyed students prefer this approach to traditional methodologies, it is also evident that, for the most part, they do not identify disadvantages in this model. The most commonly mentioned advantages are the reduction of the number of assignments to be developed over the semester and the subsequent profitability of the associated work and of the time spent.

Although there is still some optimisation work to be done, in particular as for the clarification of how the work is assessed, the respondent students expressed overall satisfaction with the clarity of the given indications and the way in which each PA contributes to the requested work.

Clearly, this approach contributes to the reinforcement of core technical competences for these students, especially as future office management professionals, in particular with regards to the preparation of the structure of different documents using multiple electronic tools and the correct writing, in terms of linguistic, discursive and structural accuracy, of different types of texts - which can be of academic or professional nature - , as well as regarding oral presentations of processes and/or results. Simultaneously, CA approaches have contributed to the development and/or consolidation of transversal competences that are highly valued by employers, such as creativity, problem solving and critical thinking. It is, therefore, clear the relevance of this pedagogical option as a leverage for the training of professionals whose profile can respond more adequately to the needs of the surrounding community and the labour market.

As a future work, it is expected not only to optimise the practices and procedures associated with the aggregations described above, but also to extend the model to other CU sets, following, for example, the experiment of aggregation (more circumscribed in time) between the CUs Electronic Office Applications I and French/German - Customer Relations and Hospitality, held in the first half of 2018/2019. 


\section{REFERENCES}

[1] C. Leite and K. Ramos, "Políticas do Ensino Superior em Portugal na fase pós-Bolonha: implicações no desenvolvimento do currículo e das exigências ao exercício docente", Revista Lusófona de Educação, vol. 28, pp. 73-89, 2015. Retrieved from http://revistas.ulusofona.pt/index.php/rleducacao/article/view/4923

[2] R. Sweetman, "HELOs and student centred learning - where's the link?", European Journal of Education, vol. 52, no. 1, pp. 44-55, 2017. Retrieved from https://onlinelibrary.wiley.com/doi/epdf/10.1111/ejed.12202.

[3] J. M. Oliveira, "Nine Years of Project-Based Learning in Engineering", Revista de Docencia Universitaria, vol. 9, no. 1, pp. 45-55, 2011.

[4] M. Borges, Secretariado: Uma Visão Prática. Lisboa: ETEP, 2015.

[5] D. Mesquita, M. A. Flores, R. M. Lima, S. Fernandes, "O contributo da formação pedagógica docente para a inovação do Ensino Superior", in Inovação Pedagógica no Ensino Superior. Ideias (e) Práticas (F. Vieira et al, orgs.), pp. 89-95, Santo Tirso: De Facto Editores, 2016.

[6] P.R. Reis and G. Camacho, "A Avaliação da concretização do processo de Bolonha numa instituição de ensino superior portuguesa", Revista Española de Educación Comparada, vol. 15, pp. 41-59, 2009. Retrieved from http://revistas.uned.es/index.php/REEC/article/view/7505

[7] C. Leite and K. Ramos, "Formação para a docência universitária: uma reflexão sobre o desafio de humanizar a cultura científica", Revista Portuguesa de Educação, vol. 25, no. 1, pp. 7-27, 2012. Retrieved from https://revistas.rcaap.pt/rpe/article/view/3014

[8] J. R. Gallego, A. Redondo, R. Lorente, A. Benedito, "La coordinación entre professores como base del nuevo aprendizaje universitario", Arxius de Ciències Socials, vol. 24, pp. 119-134, 2011. Retrieved from http://roderic.uv.es/handle/10550/19898

[9] ESTGA. Modelo de Aprendizagem, Accessed 25 February 2019. Retrieved from http://www.ua.pt/estga/PageText.aspx?id=2207

[10] J. Stroman, K. Wilson and J. Wauson, Administrative Assistant's and Secretary's Handbook. New York: American Management Association, 2012.

[11] ASP. ASP - Associação Portuguesa de profissionais de secretariado e assessoria: uma história "velha" de 33 anos, Accessed 25 February 2019. Retrieved from http://www.aspsecretarias.pt/Historia.htm

[12] M. Zárraga, M. Araluce and M. Erviti, "Propuesta de competencias para un grado en asistencia de dirección en el contexto de los nuevos planes de estudio dentro del espacio europeo de educación superior (EEES)", Intangible Capital, vol. 8, no. 2, pp. 181-215, 2012. Retrieved from http://www.intangiblecapital.org/index.php/ic/article/view/260

[13] S. Quinteiro and A. Mesquita, "O cenário da preparação dos profissionais de secretariado em Portugal - uma reflexão", in Livro de Atas CISA 2016 - O Secretariado na Competitividade Organizacional (A. M. Vieira, Coord.), pp. 79-90, Porto: Conselho Profissional de Secretariado, 2017. 